\title{
The Role of Family Function and Support to Nutritional Status in Autistic Children
}

\author{
Muhammad Khotibuddin ${ }^{1 *}$, Riska Shellia ${ }^{2}$ \\ ${ }^{1}$ Department of Family Medicine and Public Health, Faculty of Medicine and Health Sciences, Universitas Muhammadiyah \\ Yogyakarta, Bantul, Yogyakarta, Indonesia \\ 2 Faculty of Medicine and Health Sciences, Universitas Muhammadiyah Yogyakarta, Bantul, Yogyakarta, Indonesia
}

DATA OF ARTICLE:
Received: 25 Apr 2021
Reviewed: 11 Oct 2021
Revised: 23 Jan 2022
Accepted: 26 Jan 2022

CORRESPONDENCE:

muhammad_khotibuddin@yahoo.com

DOI:

10.18196/mmjkk.v21i2.11598

TYPE OF ARTICLE:

Research

\begin{abstract}
The role of the family is substantial in determining the nutritional status of children. However, not many studies have revealed this role in autistic children in Indonesia. This study aims to assess the role of family function and family support for the nutritional status of autistic children in Yogyakarta. This study used a cross-sectional design to observe at least 14 children divided into three groups: autistic-overweight, autisticnormal, and non-autistic-normal. The APGAR score measured the family function, while family support was measured by a questionnaire consisting of 5 aspects: information, respect, instrumental, emotional, and social. The difference test between the three groups used the Anova test. Total family support in the autistic-overweight group $(73.17 \pm 4.45)$ was lower than autistic-normal $(80.6 \pm 3.36)$ and non-autistic $(78.33 \pm 3.21)$. This difference was significant between autistic-overweight and autistic-normal ( $\mathrm{p}$ 0.022), but not with the non-autistic group. Furthermore, there was no difference in family function (APGAR score) between the three study groups. There was less family support among autistic-overweight children.
\end{abstract}

Keywords: Autistic Children; Family Functions; Family Support; Nutritional Status

\section{INTRODUCTION}

In Indonesia, the nutritional problem in children with special needs (ABK) is alarming. The prevalence of abnormal nutrition in children with special needs was greater than in children of the same age. The prevalence of abnormal nutrition in primary school children in Indonesia in 2013 reached $29.2 \%$, while in Yogyakarta Province, it reached $29.5 \% .^{1}$ The results of a survey on nutritional status in Special Education Schools (SLB) in Bantul found that $51 \%$ of special education school children had problems with nutritional status, which is much higher than the provincial and national averages. ${ }^{2}$ Most of the nutritional problems in children with special needs are dominated by obesity which varies from $16 \%$ in Jakarta to $42 \%$ in Pleret, Bantul. ${ }^{3}$ The prevalence of malnutrition in $A B K$ is almost the same as a prevalence in same-aged children (8-9\%). However, in Semarang, the prevalence of undernutrition in autistic children was higher (30\%). ${ }^{4}$ Most likely, the cause of the nutritional problem is multifactorial, such as nutritional intake, diseases, socio-demographic status, and family support. 5,6

Children with special needs (ABK) are likely to be less than 18 years old and have physical, mental, intellectual, and sensory disabilities (UU RI No. 8 of 2016). The prevalence of ABK in Indonesia is estimated at $5.3 \%$ of moderate-severe $A B K$ and $0.7 \%$ of severe $A B K .^{7}$ The disorder includes the blind, deaf, speech impairment, quadriplegic, mental retardation, autism, and syndrome. Around $85 \%$ of $A B K$ do not go to school and live in communities far from the government's policies or social security programs. They do not obtain enough attention and protection from their family. The lack of family support occurs due to stigma, isolation, and excessive protection from their family. ${ }^{8}$

Family support is highly necessary for the development and protection of children, especially children with special needs. ${ }^{9,10}$ Children with special needs have much difficulty in many things, such as eating behavior, leading to malnutrition due to insufficient food intake. ${ }^{11}$ The existence of family support can affect 
positive eating behavior in children. The eating process in children is a biological requirement and social interaction, respect, and establishing early good eating behavior. ${ }^{12}$ However, these roles of family support are still far from expectations in ABK. Several studies showed that family support for ABK is still low. The amount of good family support ranges from $54.3 \%$ to $56.1 \% .13,14$ The low family support for ABK can increase the risk of malnutrition through less energy intake. ${ }^{13}$ In different circumstances, the increase in obesity in $A B K$ has not been widely known with low family support or vice versa. Children who spend much time with their fathers have a higher risk of obesity than children who spend much time with their mothers. ${ }^{15}$ In addition, the researchers suggest that obesity in ABK can be associated with low family function (dysfunctional family). ${ }^{16}$

Children with autistic spectrum disorders (autism) have eating problems. There is a relationship between eating behavior, diet quality, social status, communication, and cognitive level on nutritional adequacy. The impact of eating problems on the family can lead children to malnutrition. Autistic children often avoid mealtimes, especially when it comes to unfavored smells. Frequently, they feel anxious interactions while eating. ${ }^{17}$ The nutritional status of autistic children in SLB Negeri Semarang shows that the more often the children consume high-fat foods are, the more overweight and obese they will be. The incidence of overweight and obesity in childhood can increase the risk of degenerative diseases in adulthood. Therefore, the increase of high-fat consumption in autistic children must be considered. ${ }^{4}$ Otherwise, the higher the protein consumption in autistic children is, the better the prevalence of nutritional status will increase. Energy-dense foods accompanied by a lack of physical activity will gain weight. Therefore, most autistic children have more body fat, which increases the prevalence of obesity. ${ }^{4}$

Many studies in Indonesia have the relationship between nutritional status and family support in $A B K$, but the relationship between family factors (function and support) on nutritional status in $A B K$, especially autistic, is not widely studied. It is interesting to study the relationship between family function and family support with the nutritional status of autistic children in SLB, especially in the Yogyakarta area.

\section{MATERIALS AND METHOD}

This research is an observational study with a cross-sectional design. The research population included children with special needs in Yogyakarta. They were elementary school students at the SLB Negeri 1 Bantul with a total of 144 students who were divided into classes with mild-moderate $A B K$ and severe $A B K$ (autistic and others). The sample of this study amounted to 14 children from the severe ABK class. In the sample recruitment process, researchers tried to recruit respondents in all classes, but many parents, especially those from the mild-moderate $A B K$ class, were not willing to participate in the study since they may have often been asked to be subjects in others previous studies. This study had been reviewed for ethical clearance from the institutional board.

The nutritional status was measured by body mass index (BMI) per age by gender (BMI/U). The graphic categorized those into undernutrition, normal, and overweight category. Furthermore, the subjects were re-grouping into three groups based on the combination of nutritional status and type of disability. There are autistic-overweight, autistic-normal, and non-autistic-normal groups. The independent variables consisted of (1) demographic-social status, (2) family support, and (3) family function. Social demographic status consisted of age, gender, class, economic status, and parental education. Family support was measured by an adaptation questionnaire from Sidik (2014). ${ }^{18}$ Meanwhile, the family support questionnaire consisted of 5 aspects of family support: information, respect, instrumental, emotional, and social. The Family support was categorized into good, moderate, and poor. The Family function was measured by the APGAR Score, including the functions of adaptation, partnership, growth, affection, and resolve. Family APGAR scores ranged from 0-10. The Family Function categories were divided into three: functional family (8-10), moderate dysfunction (4-7), and severe dysfunction (0-3). All measurements were taken with the help of enumerators to conduct interviews with parents to measure the children's height and weight. The Data from measurement were analyzed using the SPSS program. The Anova test was performed to identify the differences between numerical data in those three groups.

\section{RESULTS}

There were 14 children from severe ABK class only, which was included in this study. They all had severe disabilities such as autistic disorder and non-autistic severe mental retardation. The characteristics of the subjects can be seen in Table 1. Those severe ABK subjects represented from many variables, including their parents demographic characteristics, children's nutritional status, family support, and family functions. In general, the research subjects were dominated by autistic children (78.6\%), male gender (64.3\%), and most of the children's parents did not continue their education to college (78.6\%). According 
to the $C D C$, the nutritional status of children is presented as $B M I / U$, which is interpreted using the nutritional status criteria. The interpretation shows that if $\mathrm{BMI} / \mathrm{U}$ is $>85$ th percentile, the child is overweight. Otherwise, if the $\mathrm{BMI} / \mathrm{U}$ is $<85$ th percentile, the child is categorized as normal nutrition. The combination of nutritional status variables and types of disabilities (Autistic and Non-Autistic) resulted in a new group used in the ANOVA analysis to identify differences in family support and function (Table 2 and Table 3).

Table 1. Characteristics of Respondents

\begin{tabular}{|c|c|c|}
\hline $\begin{array}{l}\text { Variables } \\
\text { (Category) }\end{array}$ & $\begin{array}{l}\text { Frequency } \\
\text { (Mean) }\end{array}$ & $\%$ \\
\hline \multicolumn{3}{|l|}{ Parents' Demographics } \\
\hline Age (mean) & 42.36 & \pm 6.73 \\
\hline \multicolumn{3}{|l|}{ Gender } \\
\hline (1) Male & 3 & 21.4 \\
\hline (2) Female & 11 & 78.6 \\
\hline \multicolumn{3}{|l|}{ Education } \\
\hline (1) High (S1) & 4 & 28.6 \\
\hline (2) Basic (12 Years) & 10 & 71.4 \\
\hline \multicolumn{3}{|l|}{ Incomes $(\mathrm{Rp})$} \\
\hline (1) High (>4 million) & 4 & 28.6 \\
\hline (2) Medium (>3 million) & 3 & 21.4 \\
\hline (3) Less ( $<3$ million) & 7 & 50.0 \\
\hline \multicolumn{3}{|l|}{ Occupation } \\
\hline (1) Working & 8 & 57.1 \\
\hline (2) Housewife & 6 & 42.9 \\
\hline \multicolumn{3}{|l|}{ Childrens' Demographics } \\
\hline \multicolumn{3}{|l|}{ Gender } \\
\hline (1) Male & 9 & 64.3 \\
\hline (2) Female & 5 & 35.7 \\
\hline Age (mean) & 10.99 & \pm 1.34 \\
\hline \multicolumn{3}{|l|}{ Types of Disability } \\
\hline (1) Autistic & 11 & 78.6 \\
\hline (2) Non-Autistic & 3 & 21.4 \\
\hline \multicolumn{3}{|l|}{ Nutritional Status (IMT/U) } \\
\hline (1) Overweight (>85 percentile) & 6 & 42.9 \\
\hline (2) Normal $(<85$ percentile $)$ & 8 & 57.1 \\
\hline \multicolumn{3}{|l|}{ Autistic-Nutritional Status } \\
\hline (1) Autistic-Overweight & 6 & 42.86 \\
\hline (2) Autistic-Normal & 5 & 35.71 \\
\hline (3) Non-Autistic-Normal & 3 & 21.43 \\
\hline \multicolumn{3}{|l|}{ Family Support } \\
\hline (1) Good (79-104) & 6 & 42.9 \\
\hline (2) Enough (53-78) & 8 & 57.1 \\
\hline \multicolumn{3}{|l|}{ Aspects of Family Support } \\
\hline Information (mean) & 14.43 & \pm 2.31 \\
\hline Emotional (mean) & 22.93 & \pm 2.23 \\
\hline Respect (mean) & 12.21 & \pm 0.97 \\
\hline Instrument (mean) & 16.29 & \pm 0.99 \\
\hline Social (mean) & 11.07 & \pm 1.98 \\
\hline Total Supports (mean) & 76.93 & \pm 4.98 \\
\hline \multicolumn{3}{|l|}{ Family Function } \\
\hline (1) Good $(7-10)$ & 9 & 64.3 \\
\hline (2) Less $(<7)$ & 5 & 35.7 \\
\hline APGAR Score (mean) & 7.5 & \pm 1.70 \\
\hline
\end{tabular}

All bivariate variables were analyzed using Spearmen's test. The summary of the test's results is shown in Chart 1. The chart shows that at least two demographic characteristics are related to two aspects of family support. Those are the child's year class with respect aspect, and parent's age with the aspect of the instrument. It shows that the higher child's year class had less respect from family ( $r-0.552 ; p 0.041)$. On another side, older parents gave more support to the child through the instrument aspect ( $\mathrm{r} 0.647 ; \mathrm{p} 0.012)$. There is no significant relationship between parents' demographic characteristics and children's nutritional status and family function. The relationship between family function and family support looked highly thigh. The APGAR score had a significant relationship with family support, both categorical ( $r-0.567 ; p$ 


\section{mutiara medika \\ Jurnal Kedokteran dan Kesehatan}

$0.034)$ and total support value ( $\mathrm{r} 0.720 ; \mathrm{p} 0.004)$. In general, the nutritional status of children was related to a family function ( $r 0.631 ; p 0.016)$ and the total value of family support $(r-0.559 ; p 0.038)$. The group's category (nutritional status and disability) appeared to be related to family function only $(r-0.575 ; p 0.032)$ but not related to family support. These results proved a bivariate relationship between the nutritional status of children with special needs (ABK), family function, and family support.

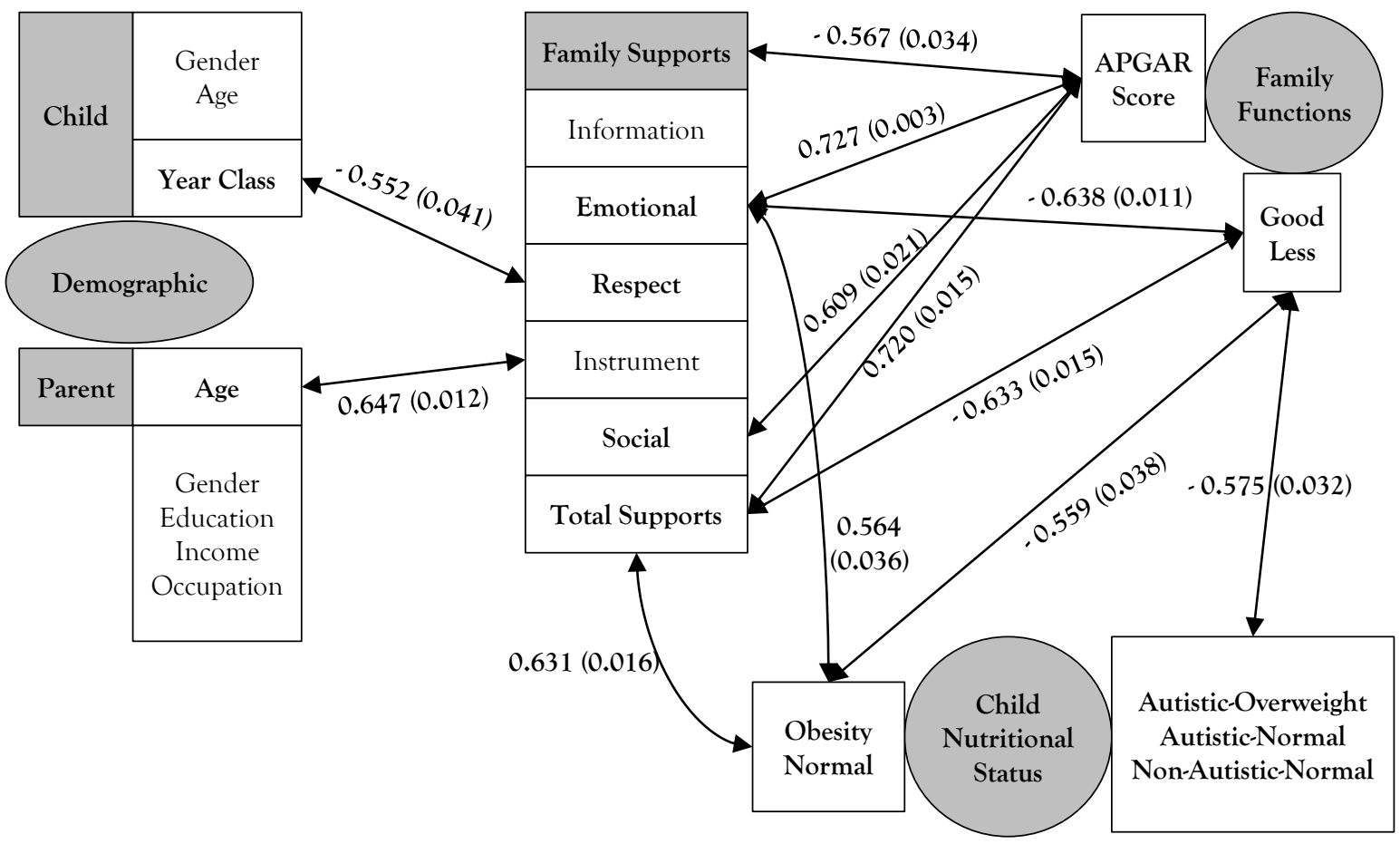

Chart 1. Summary of Spearman Correlation Test Results between Various Research Variables: The Correlation Value is Followed by the P-Value in Parentheses

The results of the ANOVA analysis of the autistic-overweight, autistic-normal, and non-autistic-normal groups showed differences in family support but not with APGAR scores (family function), as shown in Table 2. The total family support in the autistic-overweight group was lower than the non-autistic-normal and autistic-normal groups. In the Tukey HSD analysis, this difference in support only occurred in the autistic-overweight group and the autistic-normal group, while the non-autistic-normal group had no difference in family support with the two autistic groups. The difference in family support between autisticoverweight and autistic-normal was very likely due to differences in aspects of emotional support, as shown in Table 3. This analysis indicated that obesity in autistic children could be influenced by the role of family support, especially emotional support. There was no difference in the family function through APGAR score between those three groups.

Table 2. Differences in APGAR Score (Family Function), Total Support and Support Aspects by Category of Nutritional Status and Type of Childbirth

\begin{tabular}{lllll}
\hline Dependent Variables & $\begin{array}{l}\text { Autistic- } \\
\text { Overweight } \\
(\mathrm{N}=6)\end{array}$ & $\begin{array}{l}\text { Autistic- } \\
\text { Normal } \\
(\mathbf{N = 5})\end{array}$ & $\begin{array}{l}\text { Non-Autistic- } \\
\text { Normal } \\
(\mathbf{N}=3)\end{array}$ & $\begin{array}{l}\text { ANOVA } \\
(\mathbf{p}-\text { value) }\end{array}$ \\
\hline APGAR Score (Family Function) & $6.83 \pm 1.83$ & $8.0 \pm 1.58$ & $8.0 \pm 1.73$ & 0.481 \\
Total Family Supports* & $73.17 \pm 4.45$ & $80.6 \pm 3.36$ & $78.33 \pm 3.21$ & 0.025 \\
Information Aspect $_{\text {Emotional Aspect }}^{*}$ & $13.17 \pm 2.14$ & $15.2 \pm 2.17$ & $15.67 \pm 2.31$ & 0.211 \\
Respect Aspect & $21.50 \pm 2.26$ & $24.6 \pm 1.14$ & $23.0 \pm 2.0$ & 0.058 \\
Instrument Aspect & $11.67 \pm 0.52$ & $12.6 \pm 0.89$ & $12.67 \pm 1.53$ & 0.197 \\
Social Aspect & $16.33 \pm 0.82$ & $16.4 \pm 0.89$ & $16.0 \pm 1.73$ & 0.869 \\
\hline
\end{tabular}


Table 3. Analysis of the differences between the Autistic-Overweight, Autistic-Normal, and Non-Autistic-Normal groups from the APGAR Score (Family Function), Total Support, and Emotional Support Aspects

\begin{tabular}{|c|c|c|c|c|c|c|c|}
\hline Variable & $\begin{array}{l}\text { Type of } \mathrm{N} \\
\text { Disability }\end{array}$ & tional status and & Mean Diff & SE & p-value & & \\
\hline \multirow[t]{4}{*}{$\begin{array}{l}\text { APGAR } \\
\text { score }\end{array}$} & \multirow[t]{2}{*}{$\begin{array}{l}\text { Autistic- } \\
\text { Overweight }\end{array}$} & Autistic-Normal & -1.16667 & $\begin{array}{l}1.0461 \\
6\end{array}$ & 0.525 & 3.9922 & 1.6589 \\
\hline & & $\begin{array}{l}\text { Non-Autistic- } \\
\text { Normal }\end{array}$ & -1.16667 & $\begin{array}{l}1.2216 \\
5\end{array}$ & 0.619 & 4.4662 & 2.1328 \\
\hline & \multirow[t]{2}{*}{$\begin{array}{l}\text { Non-Autistic- } \\
\text { Normal }\end{array}$} & Autistic-Overweight & 1.16667 & $\begin{array}{l}1.2216 \\
5\end{array}$ & 0.619 & 2.1328 & 4.4662 \\
\hline & & Autistic-Normal & 0.00000 & $\begin{array}{l}1.2617 \\
1\end{array}$ & 1.000 & 3.4077 & 3.4077 \\
\hline \multirow[t]{4}{*}{$\begin{array}{l}\text { Total } \\
\text { Family } \\
\text { Support }\end{array}$} & \multirow[t]{2}{*}{ Overweight } & Autistic-Normal & $-7.43333\left(^{*}\right)$ & $\begin{array}{l}2.3430 \\
7\end{array}$ & 0.022 & $\begin{array}{l}- \\
13.761 \\
6 \\
\end{array}$ & 1.1050 \\
\hline & & $\begin{array}{l}\text { Non-Autistic- } \\
\text { Normal }\end{array}$ & -5.16667 & $\begin{array}{l}2.7361 \\
2\end{array}$ & 0.188 & $\begin{array}{l} \\
12.556 \\
5\end{array}$ & 2.2232 \\
\hline & \multirow[t]{2}{*}{$\begin{array}{l}\text { Non-Autistic- } \\
\text { Normal }\end{array}$} & Autistic-Overweight & 5.16667 & $\begin{array}{l}2.7361 \\
2\end{array}$ & 0.188 & 2.2232 & $\begin{array}{l}12.556 \\
5\end{array}$ \\
\hline & & Autistic-Normal & -2.26667 & $\begin{array}{l}2.8258 \\
5 \\
\end{array}$ & 0.709 & 9.8989 & 5.3656 \\
\hline \multirow[t]{4}{*}{$\begin{array}{l}\text { Emotional } \\
\text { Aspect }\end{array}$} & \multirow[t]{2}{*}{$\begin{array}{l}\text { Autistic- } \\
\text { Overweight }\end{array}$} & Autistic-Normal & $-3.10000\left(^{*}\right)$ & $\begin{array}{l}1.1357 \\
8\end{array}$ & 0.048 & 6.1676 & 0.0324 \\
\hline & & $\begin{array}{l}\text { Non-Autistic- } \\
\text { Normal }\end{array}$ & -1.50000 & $\begin{array}{l}1.3263 \\
1\end{array}$ & 0.516 & 5.0822 & 2.0822 \\
\hline & \multirow[t]{2}{*}{$\begin{array}{l}\text { Non-Autistic- } \\
\text { Normal }\end{array}$} & Autistic-Overweight & 1.50000 & $\begin{array}{l}1.3263 \\
1 \\
\end{array}$ & 0.516 & 2.0822 & 5.0822 \\
\hline & & Autistic-Normal & -1.60000 & $\begin{array}{l}1.3698 \\
0\end{array}$ & 0.495 & 5.2996 & 2.0996 \\
\hline
\end{tabular}

\section{DISCUSSION}

In this study, most autistic children were dominated by males (64.3\%), and the majority of their parents were not highly educated (78.6\%). Table 1 shows that the overweight among severe $A B K$ is $42.9 \%$ based on $\mathrm{BMI} / \mathrm{U}>85$ percentile. It indicated that obesity is a prominent nutritional problem among autistic children. There was no relationship between the type of disability and the characteristics of children and their parents with the nutritional status of children with autism (Chart 1). Epidemiological data states that autism in males is higher than in women, with a ratio of 3:1. ${ }^{19}$. The number of overweights in autistic children also reaches $50 \%$, which is multifactorial, including low parental education. ${ }^{20}$

The family support for ABK is divided into good support (42.9\%) and less support (57.1\%). None of the study subjects had a poor level of family support. According to Sidik's research (2014), the number of adequate family support (45.5\%) was greater than the good category (22.7\%). ${ }^{18}$ Although most children with special needs received family support at a sufficient or moderate level, most crew members had families that functioned well (64.3\%). It showed that a good level of family function does not always encourage good family support. These data explain why the relationship between family function and support is negative ( $r$ 0.567; p 0.034). Usually, families with autistic children will increase stress on both parents, which causes psychological problems, marital fractures, and family dysfunction. ${ }^{21}$ On the other hand, parents who are not stressed in caring for autistic children have a level of self-confidence and good perceptions, indicating a need for lower family support. ${ }^{22}$

Chart 1 shows a relationship between family support and family function on the nutritional status of autistic children. However, It cannot be directly linked as a factor that affects the nutritional status of autistic children. It occurred since the nutritional status is influenced by many factors originating from internal and external aspects. ${ }^{23}$ External factors that affect the nutritional status of children with special needs include (a) socio-economic status, (b) parental education, and (c) parental knowledge. Meanwhile, internal factors that affect the nutritional status of children with special needs include (a) Pre-natal (pregnancy infection, maternal age); (b) peri-natal (prolonged birth, premature birth, lack of oxygen, breech birth); (c) post-natal (nutrition intake, poisoning, and infection). Nutritional status is directly influenced by food intake and physical activity, whereas family parenting influences food intake. ${ }^{24}$ From this parenting pattern, a relationship can be drawn with family support and function. ${ }^{25}$ In this study, both intake and physical activity 
factors measurements were not carried out so that there was a gap analysis between support factors and family functions with the nutritional status of children with autism. Unlike the relationship between family support and family function for autistic children, these two factors can only be observed through the different groups with disabilities, further distinguished by their nutritional status. Thus, the differences in family support and family function in groups of children with autism who are autistic-overweight, autisticnormal, and non-autistic-normal as control can be identified.

Furthermore, total family support is the total value of the five aspects of support: information, respect, instrumental, emotional, and social. In the autistic-overweight group, total family support and all aspects of family support except the instrumental aspect appeared lower than the autistic-normal and nonautistic-normal groups. However, a significant difference was only found in total family support and emotional support. It supports the results of the relationship analysis obtained in chart 1 that the nutritional status of autistic children was related to the total value of family support ( $\mathrm{r} 0.631 ; \mathrm{p} 0.016)$ and aspects of emotional support ( $r$ 0.564; p 0.036). Thus, the low level of family support, especially the emotional aspect of the overweight group of autistic children, should be a concern.

This study has limitations, as stated in the previous paragraph. This study had a small sample size. Many parents were unwilling to become respondents as they were exhausted from being respondents in previous studies from other researchers. In addition, at the time of data collection, the Covid-19 pandemic period was ongoing, where all schools underwent distance learning. This situation made it more complicated, and the researchers had to make further efforts to increase samples from other schools. Besides, this study did not include and measure the variables of food intake and physical activity as direct causal factors of nutritional status. Thus, further research must include these variables in the analysis.

\section{CONCLUSION}

Based on the result of this study, it can be concluded that there was a low role of family support in the group of obese autistic children compared to non-autistic and autistic children who were not obese.

\section{CONFLICT OF INTEREST}

The authors declare no conflict of interest.

\section{REFERENCES}

1. Riset Kesehatan Dasar (Riskesdas) Tahun 2013. Departemen Kesehatan Republik Indonesia, 2013. https://pusdatin.kemkes.go.id/resources/download/general/Hasil\%20Riskesdas\%202013.pdf

2. Ardi S. Status Gizi Anak Tunagrahita Berdasarkan Indeks Massa Tubuh di SLB Tunas Bhakti Pleret. Skripsi. Yogyakarta: UNY, 2015.

3. Tamin TZ, Idris FH, Mansyur M, Syarif DR. Prevalence and Determinants of Obesity in Students with Intellectual Disability in Jakarta. Med J Indones, 2014; 23(2):106-11. https://doi.org/10.13181/mji.v23i2.688

4. Majidah UA, Fatimah S. Hubungan Pola Makan Dengan Status Gizi Anak Autism Spectrum Disorder (Asd) Kelas I - Vi Di Slb Negeri Semarang Tahun 2017. Jurnal Kesehatan Masyarakat, 2017, (5): 10.

5. Ijarotomi, OS. Determinants of Childhood Malnutrition and Consequences in Developing Countries. Current Nutrition Reports. 2013:2(3):129-133. https://doi.org/10.1007/s13668-013-0051-5

6. Kerac M, Postels DG, Mallewa M, Alusine Jalloh A, Voskuijl WP, Groce N, et al. The Interaction of Malnutrition and Neurologic Disability in Africa. Semin Pediatr Neurol. 2014;21(1):42-9. https://doi.org/10.1016/j.spen.2014.01.003

7. Pusat Data dan Informasi (Pusdatin). Situasi Penyandang Disabilitas. Jakarta: Kementerian Kesehatan RI, 2014.

8. Agus D. Program Rehabilitasi Sosial Penyandang Disabilitas dan Pergeseran Paradigma Penganganan Penyandang Disabilitas. Pusdatin 2004. Jakarta: Kementerian Kesehatan RI.

9. World Health Organization (WHO). Early Childhood Development and Disability. Geneva; 2012.

10. Neely-Barnes SL, Dia D. Families of Children with Disabilities: A Review of Literature and Recommendations for Interventions. J Early Intensive Behav Interv. 2008; 5 (3): 93-107. https://doi.org/10.1037/h0100425

11. Yousafzai AK, Filteau S, Wirz S. Feeding Difficulties in Disabled Children Leads to Malnutrition: Experience in an Indian Slum. Br J Nutr. 2003;90(6):1097-106. https://doi.org/10.1079/bjn2003991 
12. Savage JS, Fisher JO, Birch LL. Parental Influence on Eating Behavior: Conception to Adolescence. J Law, Med Ethics. 2008;35(1):22-34. https://doi.org/10.1111/j.1748-720X.2007.00111.x

13. Paramashanti BA, Rakhman A, Endriyani L. Dukungan Keluarga Berhubungan dengan Asupan Energi Anak Retardasi Mental di SLB Negeri 01 Kabupaten Bantul. JNKI, 2016;4(3):163-168. http://dx.doi.org/10.21927/jnki.2016.4(3).163-168

14. Maulidia W, Ernawaty J, Damanik SRH. Hubungan Dukungan Keluarga terhadap Kemandirian Anak Tunagrahita dalam Menghadapi Menarche. JOM FKp, 2018; 5(2):429-438

15. Mcintosh BA, Davis G, Nayga R, Anding J, Kubena K, Perusquia E, et al. Parental Time, Role Strain, and Children's Fat Intake and Obesity-Related Outcomes. 2006.

16. Vasquez-Garibay EM, Gonzalez-Rico JL, Romero-Velarde E, Sanchez-Talamantes E, Navarro-Lozano ME. and Napoles-Rodriguez F. Considerations on Family Dynamics and the Malnutrition Syndrome in Mexican Children. Gac Med Mex. 2015; 151:732-41

17. Johnson C R, Turner K, Stewart PA., Schmidt B, Shui A., Macklin E, and Hyman SL. Relationships Between Feeding Problems, Behavioral Characteristics and Nutritional Quality in Children with ASD. Journal of Autism and Developmental Disorders, 2014; 44(9), 2175-2184. https://doi.org/10.1007/s10803. 014-2095-9

18. Sidik J. Gambaran Dukungan Keluarga yang Memiliki Anak Berkebutuhan Khusus di Sekolah Khusus Kota Tangerang Selatan. Skripsi. Jakarta: UIN Syarif Hidayatullah, 2014.

19. Hodges H, Fealko C, Soares N. Autism Spectrum Disorder: Definition, Epidemiology, Causes, and Clinical Evaluation. Transl Pediatr, $2020 \quad$ Feb; 9 (Suppl): https://doi.org/10.21037/tp.2019.09.09

20. Hill AP, Zuckerman KE, and Fombonne E. Obesity and Autism. Pediatrics December 2015, 136 (6) 1051-1061; DOI: https://doi.org/10.1542/peds.2015-1437

21. Gau SSF, Chou MC, Chiang HL, Lee JC, Wong CC, Chou WJ, et al. Parental Adjustment, Marital Relationship, and Family Function in Families of Children with Autism. Research in Autism Spectrum Disorders, 2012; 6(1):263-270. https://doi.org/10.1016/j.rasd.2011.05.007

22. Arellano A, Denne LD, Hastings RP, and Hughes JC. Parenting Sense of Competence in Mothers of Children with Autism: Associations with Parental Expectations and Levels of Family Support Needs. Journal of Intellectual $\mathcal{E}$ Developmental Disability, 2019: 44(2):212-218. https://doi.org/10.3109/13668250.2017.1350838

23. Desiningrum DR. Buku Ajar: Psikologi Perkembangan Anak. Semarang: UPT Undip Press, 2012.

24. Pratiwi TD, Masrul M, dan Yerizel E. Hubungan Pola Asuh Ibu dengan Status Gizi Balita di Wilayah Kerja Puskesmas Belimbing Kota Padang. Jurnal Kesehatan Andalas, 2016; 5(3):661-665. https://doi.org/10.25077/jka.v5i3.595

25. Geroda GB. Pola Asuh dan Dukungan Keluarga terhadap Proses Penyembuhan Anak Penderita Autis di Pusat Layanan Autis Kota Samarinda Tahun 2016. Kesmas Uwigama: Jurnal Kesehatan Masyarakat, 2018; 2(2):106-111. https://doi.org/10.24903/kujkm.v2i2.317 